Contents list available at IJRED website

Int. Journal of Renewable Energy Development (IJRED)

Journal homepage: http://ejournal.undip.ac.id/index.php/ijred

\title{
Characteristics of Waste Plastics Pyrolytic Oil and Its Applications as Alternative Fuel on Four Cylinder Diesel Engines
}

\author{
Nosal Nugroho Pratama* and Harwin Saptoadi \\ Department of Mechanical and Industrial Engineering \\ Faculty of Engineering, Gadjah Mada University, Yogyakarta, INDONESIA
}

\begin{abstract}
Waste plastics recycling using pyrolysis method is not only able to decrease a number of environment pollutant but also able to produce economical and high quality hydrocarbon products. Two experiments were conducted to completely study Waste Plastic Pyrolytic Oil (WPPO) characteristics and its applications. First experiment investigated oil characteristics derived from pyrolysis process in two stages batch reactors: pyrolysis and catalytic reforming reactor, at maximum temperature $500^{\circ} \mathrm{C}$ and $450^{\circ} \mathrm{C}$ respectively. Waste Polyethylene (PE), Polypropylene (PP), Polystyrene (PS), Polyethylene Terepthalate (PET) and others were used as raw material. Nitrogen flow rate at $0.8 \mathrm{l} /$ minutes was used to increase oil weight percentage. Indonesian natural zeolite was used as catalyst. Then, second experiment was carried out on Diesel Engine Test Bed (DETB) used blending of WPPO and Biodiesel fuel with a volume ratio of 1:9. This experiment was specifically conducted to study how much potency of blending of WPPO and biodiesel in diesel engine. The result of first experiment showed that the highest weight percentage of WPPO derived from mixture of PE waste (50\%wt), PP waste ( $40 \% \mathrm{wt})$ and PS waste $(10 \% \mathrm{wt})$ is $45.13 \% \mathrm{wt}$. The more weight percentage of PE in feedstock effected on the less weight percentage of WPPO, the more percentage of $\mathrm{C}_{12}-\mathrm{C}_{20}$ content in WPPO and the higher calorific value of WPPO. Characteristics of WPPO such as, Specific Gravity, Flash point, Pour Point, Kinematic Viscosity, Calorific value and percentage of $\mathrm{C}_{12}-\mathrm{C}_{20}$ showed interesting result that WPPO could be developed as alternative fuel on diesel fuel blending due to the proximity of their characteristics. Performance of diesel engine using blending of WPPO and biodiesel on second experiment gave good result so the WPPO will have great potency to be valuable alternative liquid fuel in future, especially on stationary diesel engine and transportation engine application.
\end{abstract}

Keywords: diesel, fuel, pyrolysis, pyrolytic oil, waste plastic

Article History: Received September 24, 2013; Received in revised form December 12, 2013; Accepted January 15, 2014; Available online

How to Cite This Article: Pratama, N.N \& Saptoadi, H. (2014) Characteristics of Waste Plastics Pyrolytic Oil and Its Applications as Alternative Fuel on Four Cylinder Diesel Engines. Int. Journal of Renewable Energy Development, 3(1), 13-20. http://dx.doi.org/10.14710/ijred.3.1.13-20

\section{Introduction}

The State Ministry of Research and Technology made a plan to develop pyrolytic oil as one of new and renewable energy sources in 2005. In 2011 to 2015 (mid-term) period, Indonesia planned to take advantage of pyrolytic oil as alternative fuel blended with diesel fuel so it could be applicable on stationary diesel engines. Furthermore in 2016 to 2025 (long-term) period, the government will target to utilize blending of pyrolytic oil and diesel fuel in transport (KNRT 2005). The government intended to maximally support the

\footnotetext{
* Corresponding author: (+62) 85959696167

Email: nosalpratama@yahoo.com
}

research activity about pyrolytic oil in any application due to its high energy potential.

Plastic is one of materials that could be processed by pyrolysis to produce pyrolytic hydrocarbon products, including pyroltic oil. Plastic is basically a petroleum product that has high calorific value. The calorific value of plastics is about $46 \mathrm{MJ} / \mathrm{kg}$ approximately for PE and PS type (Boustead 1997). Waste plastics recycle technology using pyrolysis method is able to convert tertiary waste plastics into fuels, monomers or other valuable products through thermal and catalytic degradation with a little or without involving oxygen. Some parameters affect 
plastics pyrolysis process are chemical composition of raw material, temperature, heating rate, residence time, operating pressure and catalyst type (Scheirs \& Kaminsky 2006). Waste plastics recycling process involves gathering, separation, recycling process and finally restoring back to people as same or new products, either type or function (Lardinois \& Van de Klundert 1995). Waste plastics recycling techniques include mechanical recycling of plastics waste (collecting, sorting, cleaning, drying, shredding, reclamation, pelleting, etc.), chemical feedstock recycling (thermal cracking, pyrolysis, gasification, liquefaction, etc.) and energy recovery (converting waste plastics to oil and incineration) (Scheirs \& Kaminsky 2006). Efficient and low cost method development in waste plastics recycling process will provide many benefits. Therefore, research about waste plastics pyrolysis must be conducted completely and continually to support waste plastic recycling development program.

There were some previous studies which already researched influence of some parameters of operating condition in pyrolysis process on characteristics of pyrolysis products. Hlaing (2009) and Pratama et al. (2012) investigated effect using single plastics waste and mixture of plastics waste as feedstock on weight percentage of pyrolysis products. The result was pure PS waste could produce more weight percentage of liquid product than other plastics waste such as pure PE and PP waste. In addition, the higher nitrogen flowrate could increase weight percentage of liquid product (Lin 2009).

The researches using both any type of reactors and any type of experiment procedures were conducted, such as the study used thermogravimetric analyzer (Aguardo et al. 2007; Ghoshal et al. 2008), Fixed bed reactor (Williams \& Badri 2004; Serrano et al. 2009), fluidized bed reactor (Berrueco et al. 2007; Marcilla et al. 2007), Vacuum pyrolysis (Karaduman et al. 2001), but actually result of waste plastics pyrolysis using different reactor geometry could not easily be compared because weight percentages of pyrolysis products and its characteristics were not only depended on feedstock and operating condition but also depended on specifications of pyrolysis system such as dimension, type of reactor system, heat transfer efficiency and residence time (Lopez et al. 2010).

The study about characteristics of pyrolysis products and its application on diesel engine has recently begun to be developed. Generally, pyrolysis experiments gave result that pyrolytic oil, derived from plastics pyrolysis, if compared with diesel fuel nearly has similar cetane index (40-45), slightly lower calorific value $(44-46 \mathrm{MJ} / \mathrm{kg})$, has higher kinematic viscosity at low temperature, lower flash point and fire point and contained a number of chemical compounds which have wide range boiling point distribution. (Mani et al. 2010; Gunthur et al. 2011; Kumar et al. 2012; Behera et al. 2013; Pratoomyod \& Laohalidanond 2013). The test result on diesel engine by using diesel fuel blended with WPPO showed that fuels from blending of WPPO and diesel fuel need more specific fuel consumption than pure diesel fuel in equal load percentages due to lower calorific value if compared with pure diesel fuel (Pratoomyod \& Laohalidanond 2013). Mechanical efficiency, BMEP (Brake Mean Effective Pressure) and BTE (Break Thermal Efficiency) are higher when using blending of WPPO and diesel than pure diesel fuel (Gunthur et al. 2011). The engine torque and power at any speed (rpm) revealed that blending of WPPO and diesel can cause reduction of torque and power.

Although there were many researches about plastics pyrolysis but researches of waste plastics pyrolysis in production-scale using pure local plastics waste are still little reported, beside that utilization indonesian natural zeolite have not known, yet. Moreover, applications of WPPO as alternative fuel on four cylinder diesel car engines are still rare. In this work, pyrolysis of waste plastics using plastics waste from Yogyakarta was investigated. The objective of research specifically focuses on studying how big mixture of plastics waste as feedstock on pyrolysis process equipped with two stage sequentially reactors: feedstock reactor and catalytic reactor, influence oil characteristics. Furthermore, analyzing about diesel engines performance by using biodiesel fuel from Pertamina blended with some kinds of WPPO blending will be discussed and reported.

\section{Experimental Methods}

\subsection{Origin of waste plastics samples}

Waste plastics used in this study were any type of plastics waste (such as PE waste, PP waste, PS waste, PET waste and others plastics waste) obtained from several places around Yogyakarta. The PE waste was collected from Wates, Yogyakarta and other types of plastics waste were collected from Bank Sampah, Bantul, Yogyakarta.

\subsection{Pyrolysis Experiment}

The research of pyrolysis experiment was sequentially conducted using two stages reactor: pyrolysis and catalytic reforming reactor, at maximum temperature $500^{\circ} \mathrm{C}$ and $450^{\circ} \mathrm{C}$ respectively. Nitrogen flow rate at $0.8 \mathrm{l} / \mathrm{minute}$ was used to increase oil weight percentage. Liquid product derived from pyrolysis was 


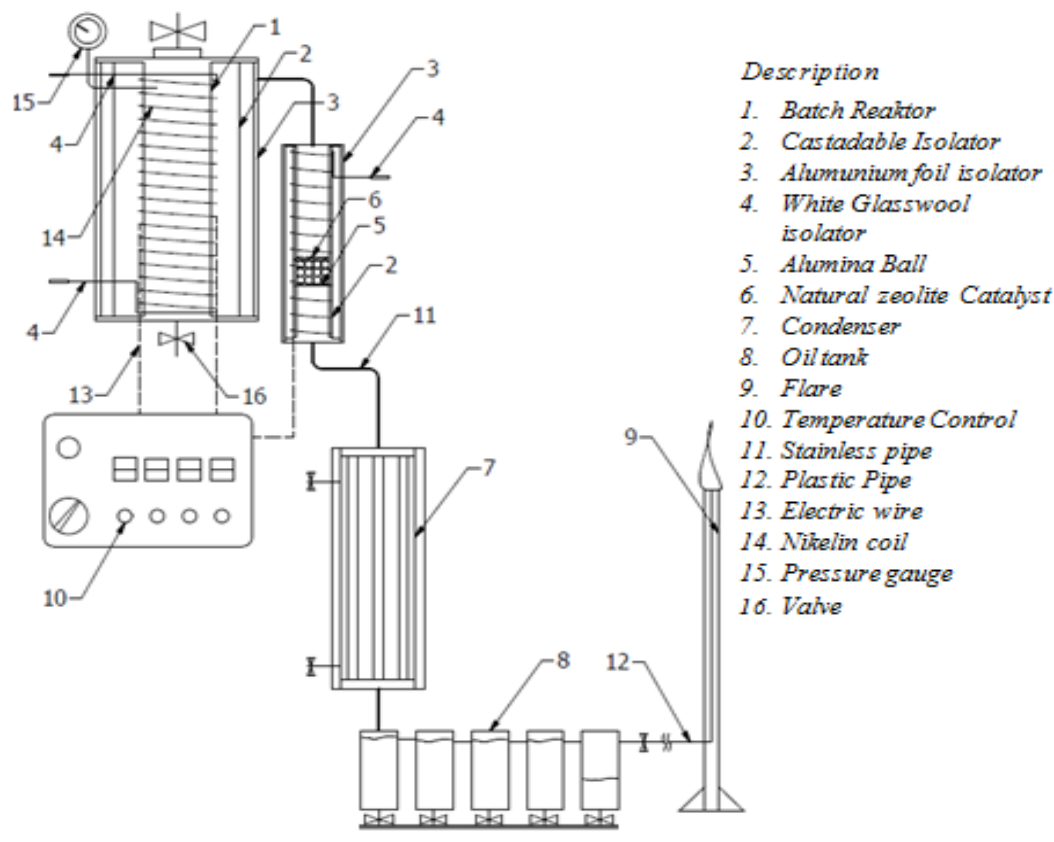

Fig. 1 Experiment Equipment of Pyrolysis

collected into oil container. Incondensable gas continually flows to the flare to be burned. Solid product could be taken in bottom of feedstock reactor after pyrolysis process is over. Generally, experiment equipments can be seen in Fig 1.

\subsection{Analytical Methods}

A total of $19.5 \mathrm{~kg}$ of waste plastics (PE, PP, PS, PET and Others) was used as a raw material. The four (4) samples used are sample 'A' (1P: 100\%wt PE), sample 'B' (2P: 60\%wt PE +40\%wt PP), sample 'C' (3P: 50\%wt $\mathrm{PE}+40 \%$ wt PP +10\%wt PS) and sample ' $\mathrm{D}$ ' (4P + 0: $50 \%$ wt PE $+30 \%$ wt PP $+10 \%$ wt PET $+5 \%$ wt PS + $5 \%$ wt others). Firstly, a sample of plastic waste is inserted into feedstock reactor, after that the catalyst reactor temperature begin to raise up to $450^{\circ} \mathrm{C}$ in order to activate the natural zeolite, after that feedstock reactor temperature is raised from room temperature up to maximum $500^{\circ} \mathrm{C}$ approximately. On the first test, the liquid product (WPPO) was tested in some UGM laboratories to determine oil characteristics such as Specific gravity (ASTM D1928), Kinematic viscosity at $40^{\circ} \mathrm{C}$ (IKU/4.5/tk-02), pour point (ASTM D5949), flash point (ASTM D93), ash content and water content. Chemical compounds and carbon number distribution percentages of WPPO were analyzed by using GC-MS (Gas Chromatography Mass Spectroscopy). Calorific value was calculated from experiment using Bomb Calorimeter. On the second test, waste plastic pyrolytic oil quality was tested on Diesel Engine Test Bed (DETB). The test was carried out by changing speed of diesel engine at 1600, 1800, 2000, 2300 and $2500 \mathrm{rpm}$ without doing any modification on diesel engine. Performance of diesel engine using blending of WPPO and biodiesel with a volume ratio 1:9 was compared. Some parameters of diesel engine performance were calculated such as the torque, power, specific fuel consumption, BMEP and BTE.

Table 1

Specification of Diesel Engine Test

\begin{tabular}{ll}
\hline Specification & Remaks \\
\hline Engine & Nissan Diesel SD22 Series \\
Parameter & Value/Dimension \\
Displacement & $2164 \mathrm{cc}$ \\
Cooler & Water \\
Compression ratio & $22: 1$ \\
Bore & $83 \mathrm{~mm}$ \\
Stroke & $100 \mathrm{~mm}$ \\
Engine Cylinder & 4 \\
\hline
\end{tabular}

\section{Result and Discussion}

\subsection{Weight Balance and Calorific Value}

Pyrolysis of waste plastics using a variety of plastics waste composition resulted differences in the percentage of pyrolysis products, calorific value and carbon number distribution. 100\%wt PE waste (sample ' $A$ ') is used as a reference to determine the effect of mixed plastic waste. Although the percentages of plastic raw materials were mostly dominated by PE waste for all samples, but there were significant unique trend on both oil characteristics and weight balance of pyrolysis products among themselves. The lowest percentage of WPPO derived from sample 'A'. Sample 'A' also produced the highest percentage of solid product. The addition of PP waste, PS waste, PET waste and others in sample ' $\mathrm{B}$ ', sample 'C' and sample ' $\mathrm{D}$ ' produced higher 


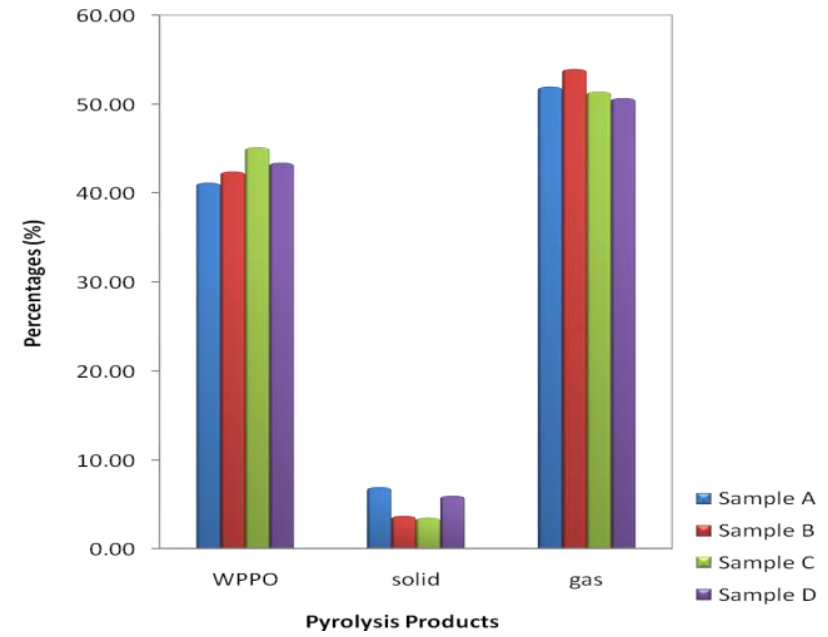

Fig. 2 Effect plastic waste composition on percentage of pyrolysis products

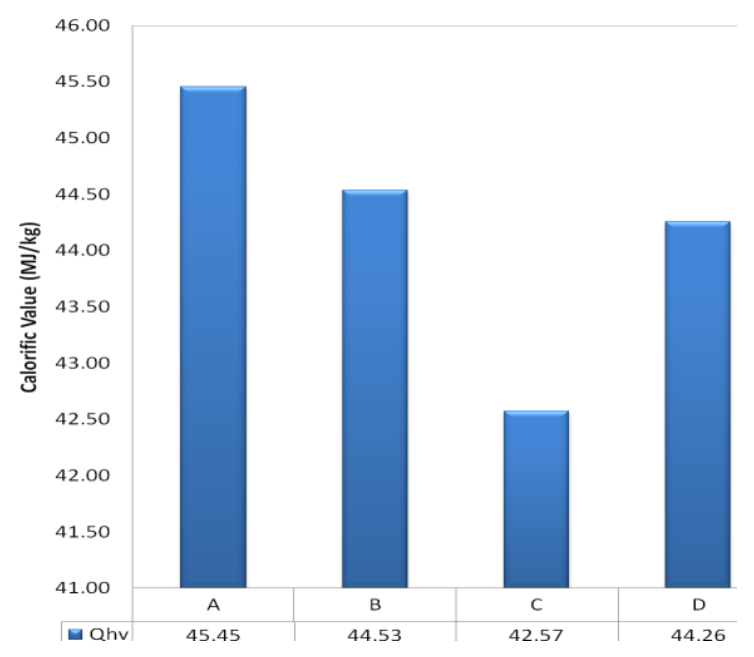

Fig. 3 Calorific value of WPPO

percentage of WPPO than $100 \%$ wt PE waste (sample ' $A$ '), on the contrary the calorific value contained in the WPPO decreased, see Fig. 2 and 3.Sample 'B' produced the highest gas product. Mixture of $40 \%$ wt PP waste and $60 \%$ wt PE waste cause the higher amount of gas, whereas the lower calorific value. The addition of $10 \%$ wt PS and 40\%wt PP (sample 'C') produced the highest percentage of WPPO at $45.13 \%$ wt but the lowest percentage of the gas product. This happened due to PS has a stable benzene ring and a high content of aromatic compounds (Pinto, 1999). The effect of adding PET and other can be seen from the percentage of the pyrolysis products at sample 'D'. Presence of $15 \%$ wt PET waste, 5\%wt PP waste, $30 \%$ wt PP waste, $5 \%$ wt other waste aside from 50\%wt PE waste produced WPPO at $43.40 \% \mathrm{wt}$, slightly lower than sample ' $C$ '. Particularly, the process of converting waste plastic into oil, gas and solid is influenced by the -

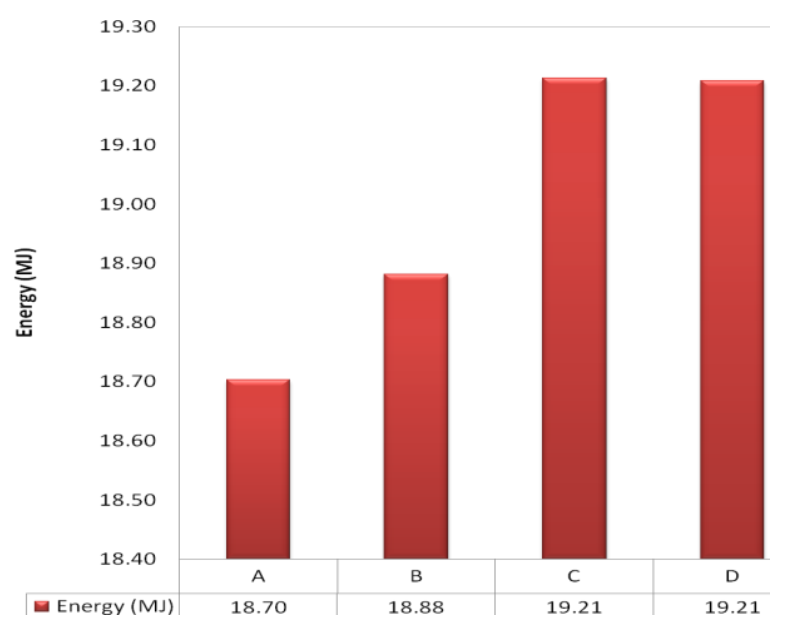

Fig. 4 Energy calculation contained on $1 \mathrm{~kg}$ sample of feedstocks

-crystalline and form of hydrocarbon structure. The less crystalline or the more branching structure of hydrocarbons, the less stable the pyrolysis process (Achilias, 2008). Fig. 4 reveals estimation energy contained per $1 \mathrm{~kg}$ sample. The Energy was calculated by multiplying calorific value and weight percentage of WPPO. Surprisingly, although WPPO from PE waste has the highest calorific value $(\mathrm{MJ} / \mathrm{kg}$ ) but waste $3 \mathrm{P}$ has the highest energy contained per $1 \mathrm{~kg}$ sample due to the highest WPPO weight percentage.

\subsection{Liquid Hydrocarbon Compound}

WPPO contains many hydrocarbon compounds both light and heavy fractions and from the lowest carbon atom number $\left(\mathrm{C}_{4}-\mathrm{C}_{5}\right)$ to the highest one $\left(>\mathrm{C}_{20}\right)$. WPPO could be classified into 3 groups to easily identify the trend of similarity between pyrolytics oil and commercial fuels (diesel or gasoline).

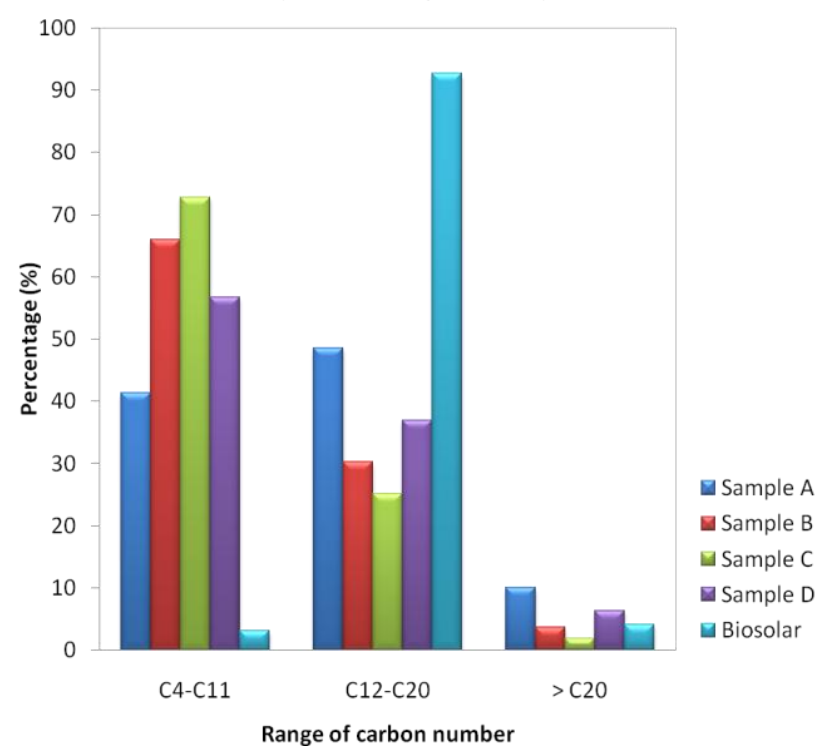

Fig. 5 Three main groups of carbon fractions in the oils 
$\mathrm{C}_{4}-\mathrm{C}_{11}$ group represents light or gasoline fraction due to the tendency that the largest percentage of the carbon atom number in the gasoline is commonly around $\mathrm{C}_{7}, \mathrm{C}_{8}$ and $\mathrm{C}_{9} \cdot \mathrm{C}_{11}-\mathrm{C}_{20}$ group could represent medium and heavy fractions, including diesel fraction. The diesel fuel fraction mostly contains high percentage of the atom number $\mathrm{C}_{16}-\mathrm{C}_{20}$. The result of this study showed that plastics waste composition strongly influence propensity formation of certain hydrocarbons group. Single PE waste leads to form mostly $\mathrm{C}_{12}-\mathrm{C}_{20}$ fraction. The $2 \mathrm{P}$ and $3 \mathrm{P}$ waste gradually decrease heavy fraction and increase percentage light oil fraction or $\mathrm{C}_{4}-\mathrm{C}_{11}$ group then percentage of $\mathrm{C}_{12}-\mathrm{C}_{20}$ group go up slightly on $4 \mathrm{P} /$ other waste, higher than $3 \mathrm{P}$ waste, as seen in Fig 5.

\subsection{Oil Properties}

Comparison between WPPO and biodiesel properties could be seen in Table 2. Specific gravity of all WPPO has proximity value with biodiesel but kinematic viscosity of themselves still rather lower than biodiesel. For utilization on diesel fuel blending is still tolerable based on these parameters due to ease in mixing and ability to flow well. WPPO of Sample 'A' favourably has same pour point value with biodiesel at $6^{\circ} \mathrm{C}$ but Pour point of others WPPO gradually drop. Water content of all WPPO is still higher than biodiesel due to humid plastics waste. Ash content from 100\%wt PE waste was the highest at $0.535 \%$ wt. The addition of PP waste, PS waste, PET waste and other can decrease ash content of WPPO compared to $100 \%$ wt PE waste.

Table 2

Oil Properties of WPPO and Diesel Fuel

\begin{tabular}{|c|c|c|c|c|c|c|}
\hline \multirow[t]{2}{*}{$\begin{array}{c}\text { Oil } \\
\text { property }\end{array}$} & \multirow[t]{2}{*}{ Unit } & \multicolumn{4}{|c|}{ WPPO } & \multirow{2}{*}{$\begin{array}{c}\text { Diesel } \\
\text { Fuel }\end{array}$} \\
\hline & & A & $\mathrm{B}$ & $\mathrm{C}$ & $\mathrm{D}$ & \\
\hline $\begin{array}{c}\text { Specific } \\
\text { Gravity at } \\
60 / 60^{\circ} \mathrm{F}\end{array}$ & - & 0.8125 & 0.866 & 0.868 & 0.8719 & 0.8445 \\
\hline $\begin{array}{c}\text { Kinematic } \\
\text { Viscosity at } \\
40^{\circ} \mathrm{C}\end{array}$ & $\mathrm{mm}^{2} / \mathrm{s}$ & 1.19 & 1.183 & 1.052 & 1.291 & 4.012 \\
\hline Flash Point & ${ }^{\circ} \mathrm{C}$ & \multicolumn{4}{|c|}{ Already flashed at $10^{\circ} \mathrm{C}$} & 66.5 \\
\hline Pour Point & ${ }^{\circ} \mathrm{C}$ & 6 & 3 & -21 & -6 & 6 \\
\hline $\begin{array}{l}\text { Water } \\
\text { Content }\end{array}$ & \%vol & 0.4 & 0.6 & 0.6 & 0.6 & 0.05 \\
\hline $\begin{array}{c}\text { Ash } \\
\text { Content }\end{array}$ & $\% w t$ & 0.535 & 0.001 & 0.05 & 0.037 & 0.01 \\
\hline
\end{tabular}

\subsection{Diesel Engine Performance}

\subsubsection{Engine Torque}

The blending of biodiesel fuel and WPPO influences the engine torque. Figure 6 shows the relation between engine torque and engine speed. The curves are created by polynomial approach. The engine torque increase by decreasing engine speed from 2500 to $1800 \mathrm{rpm}$ but after engine speed is slowed down until reach $1600 \mathrm{rpm}$ the torque of engine instead decrease. This is happened due to augmentation in mechanical loss. A10BD90 has the higher engine torque at any rpm than other blending type, the second is B10BD90 then following by D10BD90 and finally the lowest one is C10BD90. Actually, the engine torque from all blending of WPPO and biodiesel fuel can compete with BD100 because there is no big differences value among them. The curves of all blending fuels are slightly lower than pure biodiesel fuel. The maximum engine torque from pure biodiesel and biodiesel blended with WPPO from sample 'A', 'B', 'C' and 'D' were obtained around at 1800 rpm is 122.794 N.m, 121.917 N.m, 121.039 N.m, 119.286 N.m and 120.163 N.m respectively. The main reason of torque reduction was considered from slighly lower heting value of WPPO (Pratoomyod et al. 2013) and good mixture formation (Gunthur et al. 2011).

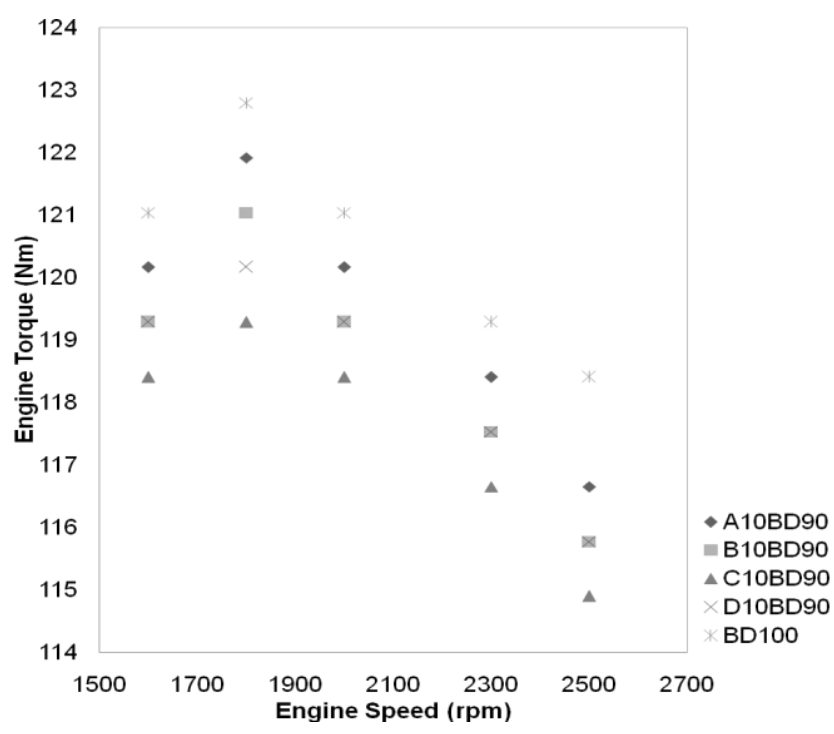

Fig. 6 Engine torque as function of engine speed for pure biodiesel and blending of WPPO and biodiesel

\subsubsection{Engine Power}

The power engine curves resulted from all blending of WPPO and biodiesel and pure biodiesel fuel have been compared as seen in Fig 7. The linier curve approch used to analyze the trends of engine power. Once again, pure biodiesel fuel still better than blending of WPPO and biodiesel fuel based on this parameter.

The engine power of pure biodiesel fuel is still slighly higher than all WPPO. The reduction of engine speed effect on decreasing the engine power. Favourably, Engine power of all WPPO at any rpm are approximately in line. Among the all WPPO, A10BD90 has the highest engine power. The lowest one is obtained from C10BD90. High calorific value takes big role to produce high engine power. 


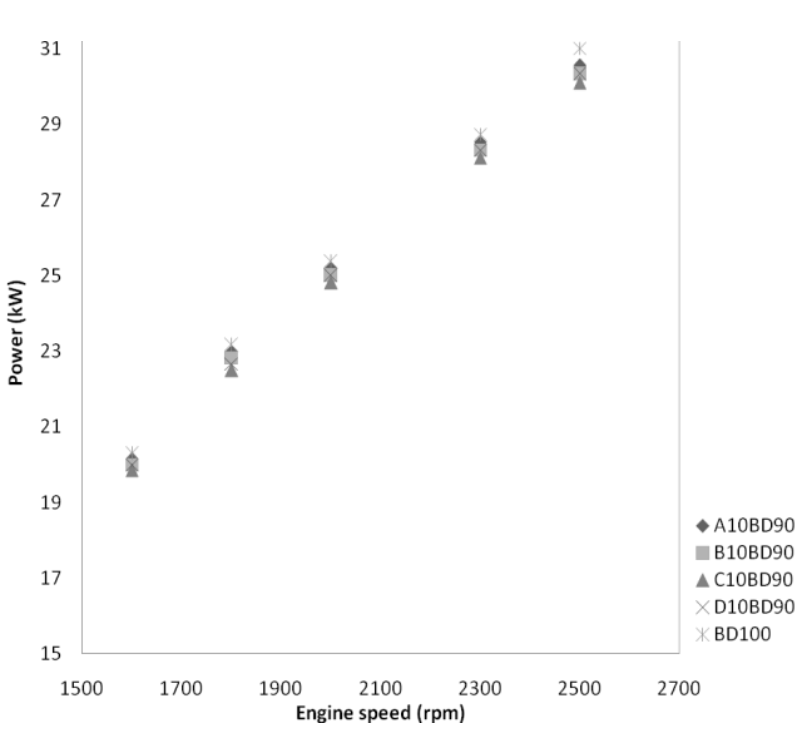

Fig. 7 Engine power as function of engine speed for pure biodiesel and blending of WPPO and biodiesel

\subsubsection{BMEP (Break Mean Effective Pressure)}

The Brake Mean Effetive Pressure (BMEP) for both all blending of WPPO and biodiesel and pure biodiesel fuel is shown in figure 8. The BMEP is obtained by deviding the work per cycle by the cylinder volume displaced per cycle (Heywood JB,1988). The Higher BMEP in equal both engine speed and cylinder geometry indicates that engine exert the higher power per cycle, and vice versa. The figure 7 showes that biodiesel fuel has the highest BMEP, this means that when using biodiesel fuel, diesel engine produces the the highest power at any engine speed, the second one is A10BD90, next is B10BD90 then D10BD90 and the last is C10BD90. All curves show equal trends.

By decreasing engine speed from 2500 to 1800 rpm, BMEP moves up until reach the maximum point at $1800 \mathrm{rpm}$ but then down at $1600 \mathrm{rpm}$. The maximum BMEP of pure biodiesel fuel and biodiesel blended with WPPO from sample ' $A$ ', ' $B$ ', ' $C$ ' and ' $D$ ' were approximately obtained at $1800 \mathrm{rpm}$ which is 712.997 $\mathrm{kPa}, 707.904 \mathrm{kPa}, 702.812 \mathrm{kPa}, 692.626 \mathrm{kPa}$ and $697.719 \mathrm{kPa}$ respectively.

Generally Calorific value, specific gravity, viscosity and volatiliy take big role in internal combustion engine, especially in torque, power and BMEP of diesel engine (Gunthur et al. 2011).

\subsubsection{SFC (Specific Fuel Consumption)}

In engine test, the fuel consumption is measured as a flow rate or weight flow per unit time. A more useful parameter is the specific fuel consumption (SFC). SFC is defined by fuel flow rate per unit power output. It measure how efficiently an engine is using the fuel supplied to produce work. Low values of SFC are

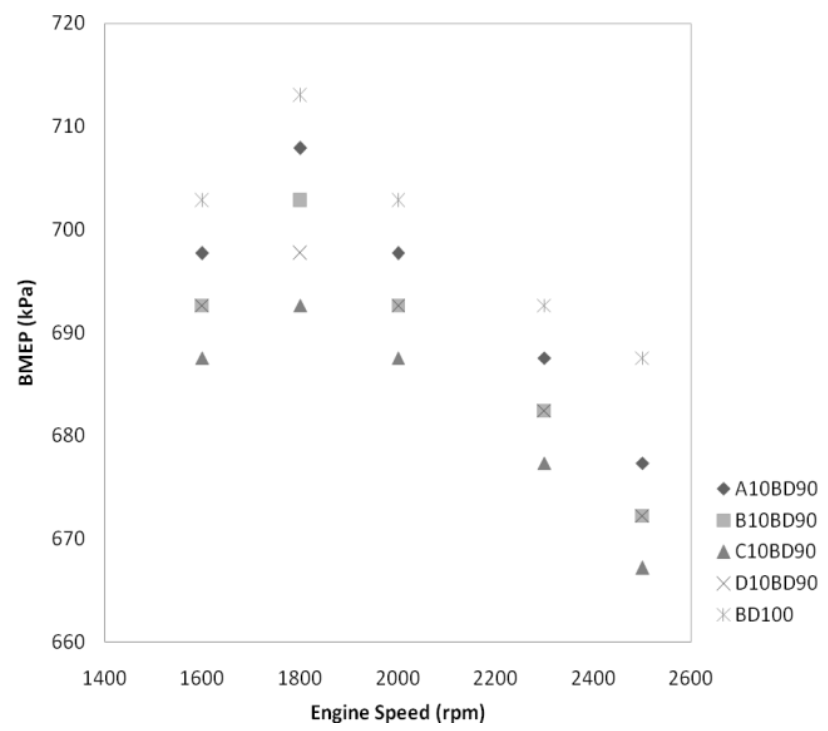

Fig. 8 BMEP as function of engine speed for pure biodiesel and blending of WPPO and biodiesel

-obviously desirable. In figure 8 shows SFC of WPPO and biodiesel. The higher engine speed, the higher specific fuel consumption as seen in Fig. 9. Interestingly, B10BD90 has lower SFC than BD100 (100\%wt biodiesel fuel). The highest SFC is achieved from D10BD90 due to high specific gravity, low kinematic viscosity and short time period when cunsuming the similar amount of fuels. Plastics mixture as raw material on pyrolysis clearly give influence on how efficiently fuel used on diesel engines.

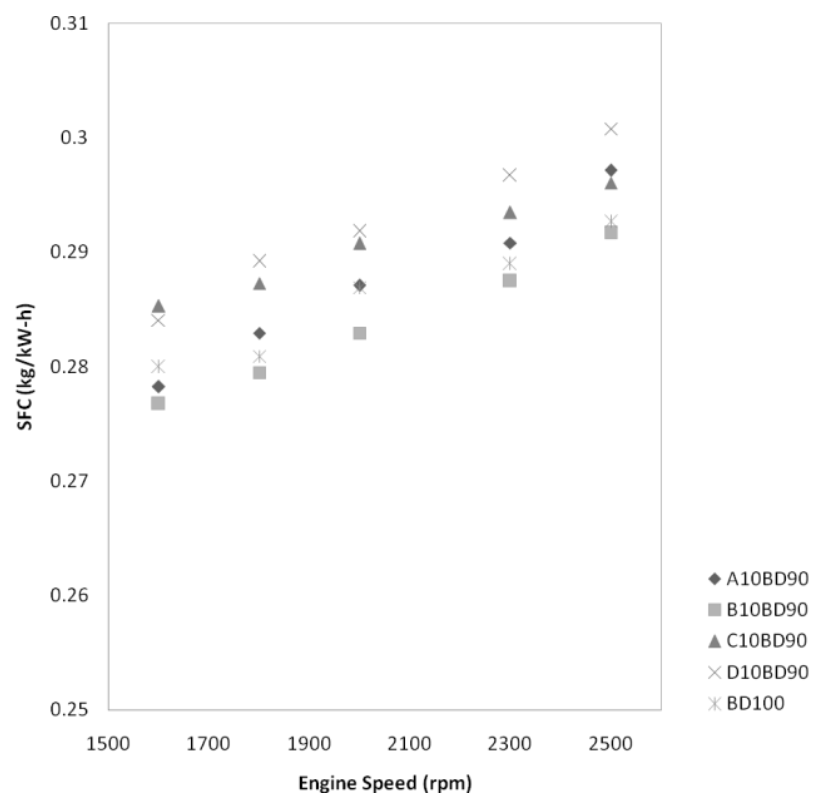

Fig. 9 Specific Fuel Consumption (SFC) as function of engine speed for pure biodiesel and blending of WPPO and biodiesel 


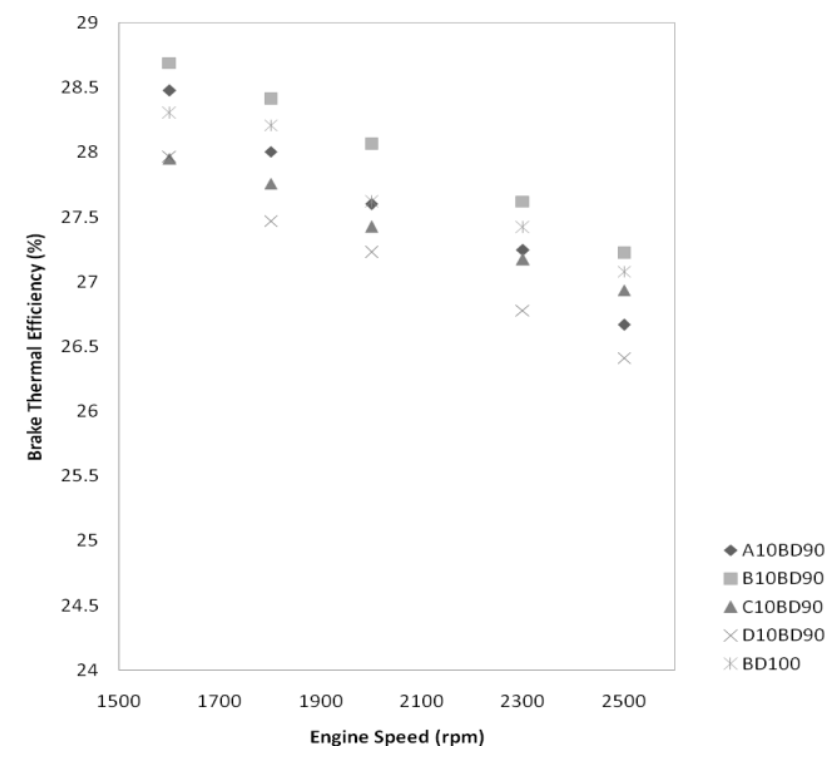

Fig. 10 Brake Thermal Efficiency (BTE) as function of engine speed for pure biodiesel and blending of WPPO and biodiesel

\subsubsection{BTE (Brake Thermal Efficiency)}

Fig. 10 shows comparison of brake thermal efficiency vs engine speed for different biodiesel blended with WPPO and pure Pertamina biodiesel. Brake thermal efficiency actually measures ratio of the brake power to heat of combustion supply by fuel. Surprisingly, B10BD90 results the highest break thermal efficiency. The second highest one is pure biodiesel, following with A10BD90, then BD100, after that D10BD90 and the last is D10BD90. The highest BTE is $28.688 \%$ at $1600 \mathrm{rpm}$ by using B10BD90 which is $1.4 \%$ higher as compared to pure biodiesel. The higher engine speed actually increases brake thermal efficiency when diesel engine is operated at 1600-2500 rpm.

\section{Conclusion}

The blending of WPPO and biodiesel fuel is feasibly to be utilized on diesel engine due to proximity of its significant fuel characteristics (such as specific gravity, kinematics viscosity, flash point and calorific value) and its diesel engine performance (such as Power, torque, BMEP, SFC and BTE. Those oil properties of WPPO are favorably appropriate to be developed as alternative fuel on diesel fuel blending. Oil derived from 100\%wt PE produced the lowest weight percentage of WPPO. The more weight percentage of PE waste, the less WPPO weight percentage produced. The highest weight percentage of WPPO was derived from 3P at $45.13 \% \mathrm{wt}$ but in terms of energy estimation per $1 \mathrm{~kg}$ sample, Mixture of $3 \mathrm{P}$ is the best one. However, liquid from PE waste had the highest calorific value. Plastics waste composition highly influence tendency of range atom carbon number formation, PE waste lead to form heavy fraction or diesel fraction whereas mixture of plastics waste lead to for light fraction or gasoline fraction. Calorific value, specific gravity and viscosity influence the engine torque, engine power, BMEP and SFC. Generally, Torque, Power and BMEP from 100\%wt biodiesel fuel are still little better than blending of WPPO and biodiesel, but fuel from blending of WPPO and biodiesel still could show good engine performance. As compared to fuels from blending of WPPO and biodiesel, A10BD90 gives the better engine performance related to torque, power and BMEP whereas B10BD90 gives the better one related to SFC and BTE.

\section{Nomenclatures}

$\begin{array}{ll}\text { WPPO } & \text { Waste Plastics Pyrolytic Oil } \\ \text { A10BD90 } & \text { 10\%vol WPPO of sample A + 90\%vol biodiesel } \\ \text { A10BD90 } & \text { 10\%vol WPPO of sample B + 90\%vol biodiesel } \\ \text { A10BD90 } & \text { 10\%vol WPPO of sample C + 90\%vol biodiesel } \\ \text { D10BD90 } & \text { 10\%vol WPPO of sample D + 90\%vol biodiesel } \\ \text { BD100 } & 100 \% \text { vol Biodiesel (from Pertamina, FAME 7.5\%vol ) } \\ \text { 1P } & \text { A (100\%wt PE waste) } \\ \text { 2P } & \text { B (60\%wt PE waste,40\%wt PP waste) } \\ \text { 3P } & \text { C (50\%wt PE waste, 40\%wt PP waste, 10\%wt PS waste) } \\ \text { 4P/others } & \text { D (50\%wt PE waste, 30\%wt PP waste, } 5 \% \text { wt PS } \\ & \text { waste,10\%wt PET waste, 5\%wt others) }\end{array}$

\section{Acknowledgements}

This research project was funded by JICA under the AUN-SEED Net, in program namely CRI (Collaborative Research with Industry). Its supports are hereby gratefully acknowledged. The Author also sincerely thank to Mochamad Syamsiro, Putri Noviasri, Tinton Norsujianto, Prabuditya Bhisma W, Gunawan Budi S, Danni Kurniawan and Sutoyo as a team mates in plastics waste-to-oil research group at Conversion Energy Laboratory, Gadjah Mada University, for having made solid cooperation.

\section{References}

Achilias, D.S., Antonakou E., Roupakias C., Megalokonomos P. \& Lappas A. (2008) Recycling techniques of polyelefins from plastic waste. Global NEST Journal, 10(1), 114-122

Behera, P. \& Marugan, S. (2013) Combustion, performance and emsission parameters of used transformer oil and its diesel blends in DI diesel engine. Journal of Fuel, 104, 147-154

Berrueco, C., Mastral, J.F. \& Ceamanos, J. (2007) Modeling of the pyrolysis of high density polyethylene: product distribution in a fluidized bed reactor. Journal of Analytical and Applied Pyrolysis, $79,313-322$

Bousteead, I. (1997) Eco-Profiles of European Plastics Industry, Report 4: Polystyrene, $2^{\text {nd }}$ Edition, Association of plastics manufactures in Europe, Brussels, Belgium

Ghoshal, A.K., Saha, B. \& Karthik Reddy, P. (2008) Hybrid genetic algorithm to find the best model and the globally optimized overall kinetics parameters for thermal decomposition of plastics. Chemical Engineering Journal, 138, 20-29

Gunthur, R., Kumar, D. \& Reddy, VK. (2011) Experiment evaluation a diesel engine with blends of diesel-plastic pyrolysis oil, 
Citation: Pratama, N.N \& Saptoadi, H. (2014) Characteristics of Waste Plastics Pyrolytic Oil and Its Applications as Alternative Fuel on Four Cylinder Diesel Engines. Int. Journal of Renewable Energy Development, 3(1), 13-20, doi: 10.14710/ijred.3.1.13-20

$\mathrm{P}$ a g e $\mid \mathbf{2 0}$

International Journal of Engineering Science and Technology, ISSN: 0975-5462

Scheirs, J. \& Kaminsky W. (2006) Feedstock Recycling and Pyrolysis of Waste Plastics: Converting Waste Plastics into Diesel and Other Fuels, ISBN: 0-470-02152-7, John Wiley \& Sons Ltd, Chichester.

Karaduman, A., Simsek, E.H., Cicek, B. \& Bilgesü, A.Y. (2001) Flash pyrolysis of polystyrene wastes in a free-fall reactor under vacuum. Journal of Analytical and Applied Pyrolysis, 60, 179-186

Kementrian Negara Riset dan Teknologi Republik Indonesia. (2006) Buku Putih Penelitian, Pengembangan dan Penerapan Ilmu Pengetahuan dan teknologi Bidang Sumber Energi Baru dan Terbarukan untuk Mendukung Keamanan Ketersediaan Energi Tahun 2005 - 2025, Jakarta

Kumar, S., Panda A.K Singh R.K. (2011) A review of tertiary of highdensity polyethylene to fuel. Journal of Resources, conversion and recycling, 55, 893-910

Lardinois, I. \& van de Klundert, A. (1995) Plastic Waste. Options for Small-Scale Resource Recovery. TOOL Publications, Amsterdam

Lin, Y.H. (2009) Production of valuable hydrocarbons by catalytic degradation of a mixture of post-consumer plastic waste in a fluidized-bed reactor. Journal of Polymer Degradation and Stability, 1924-1931

Lopez, A., Marco, I., Cabllero, D.M., Laresgoiti M.F. \& Adrados (2011) Influence of time and temperature on pyrolysis plastic wastes in a semi-batch reactor. Chemical Engineering Journal, 173, 62-71
Mani, M., Nagarajan G. \& Sampath S. (2010) An experiment on a DI diesel engine using waste plastic oil with exhaust gas recirculation. Journal of Fuel, 89, 1826-1823

Marcilla, A., Hernández, M.R., Gómez, A., García, A.N. \& Agulló, J. (2007) Effect of the temperature in the nature and extension of the primary and secondary reactions in the thermal and HZSM-5 catalytic pyrolysis of HDPE. Applied Catalysis A: General, 317, 183194

Pratama, N.N. (2012) Analisis Karakteristik minyak hasil pirolisis plastik Polyethylene, Polypropylene dan Polystyrene, Bachelor Thesis. Mechanical and Industrial engineering Department, UGM, Yogyakarta

Pratoomyod J. \& Laohalidanond K. (2013) Perfomance and emission of blends of diesel fuel with waste plastic oil in a diesel engine. International Journal of Engineering Science and Technology, ISSN: 2319-5967

Serrano, D.P., Aguardo, J., Escola, J.M. \& Garagorri, E. (2001) Conversion of low density polyethylene into petrochemical feedstock using a continuous screw kiln reactor. Journal of Analytical and Applied Pyrolysis, 58-59, 789-801

Williams, P.T. \& Badri, R. (2004) Hydrocarbon gases and soils from the recycling of polystyrene waste by catalytic pyrolysis. International Journal of Energy Research, 28, 31-44. 